\title{
Developing digital retail services as a tool of ensuring consumer market sustainable development in the Sverdlovsk region
}

\author{
Mikhail Loginov, Natalia Usova*, and Elvira Nedorostkova \\ The Russian Presidential Academy of National Economy and Public Administration, 8 Marta Str., 66, \\ 620144 Ekaterinburg, Russia
}

\begin{abstract}
The article is devoted to the development of the digital retail services as the most effective and innovative tool to reinforce the Sverdlovsk regional consumer market in the context of global challenges which had a notable impact on the sustainable development of both the economy as a whole and its individual sectors.

Research subject: digitalization of the consumer market of the Sverdlovsk region

Research purpose: to explore the theoretical foundations of the consumer market, and to identify the priority directions of the Sverslovsk regional consumer market development on the based on the digital technologies introduction.

Research methods. In the course of the research, the authors used such methods as analysis, grouping, comparison and synthesis.

Results:

1.The development features of retail trade services as a key segment of consumer market are revealed.

2.The author's approach to the "digital consumer market" category and the digital consumer market classification on various grounds are presented.

3.The priority directions of the Sverdlovsk regional consumer market development from the regional authorities's viewpoint are considered.

4. Activities for the further Sverslovsk regional consumer market development based on digital retail services advancement are proposed.

Scientific novelty: the introduction of the category "digital consumer market" into scientific circulation is proposed and substantiated, classification criteria for the digital consumer market are formulated, measures are proposed to ensure sustainable development of the consumer market in the Sverdlovsk region.
\end{abstract}

\section{Introduction}

Over the last few years the national economy of the Russian Federation has been undergoing the transition to digital economy affecting both regional and local development

\footnotetext{
* Corresponding author: nata-ekb-777@yandex.ru
} 
level. The available program documents and action plans on digital transformation served as the basis for transformations at regional level.

At this stage, a number of program documents are in force aimed at the digital transformation of the national economy. First, the Decree of the President of the Russian Federation of May 7, 2018 № 204 "On national goals and strategic objectives of the development of the Russian Federation for the period up to 2024" [1], which is to ensure the accelerated introduction of digital technologies into economic and social fields.

Second, the "Digital economy of the Russian Federation" national program [2], including a number of national projects aimed at digital environment regulatory framework development, digital economy staffing and digital public services provision, as well as digital technologies and informational infrastructure development

Importantly, there are still no approved strategic documents to develop the digital retail services. In 2017 the draft "Strategy for the development of electronic commerce in the Russian Federation for the period up to 2025" was published [3]. This strategic document identifies the main task to create additional market mechanisms aimed at ensuring growth and development of the national e-commerce market, considering the anticipated external and internal conditions, and efficient use of its resources and potential. The document has not been approved yet, affecting the digital retail services development trends.

One should admit that 2020 has introduced its own adjustments to national and regional economy development. In particular, the new global challenge, the Covid-19 coronavirus infection pandemic, has challenged the world with a great trial of maintaining sustainable regional development. The digital retail services development can be percieved as a logical extension of the retail evolution and the regional consumer market transformation.

The consumer market includes three segments: retail services market, catering services market and paid services market, but the key is the retail services market.

The aim of this research is to investigate the regional consumer market of the Sverdlovsk region and to ensure its sustainable development based on digital retail services in modern conditions.

This provided for the tasks to be solved in the article, in particular: to reveal the consumer market essence and the issues of consumer market development under consideration, to identify the digital consumer market specifics and its classification features, to consider the strategic document giving the priority directions of consumer market development in the Sverdlovsk region, to justify the advancement of retail trade digital services as a tool to ensure sustainable development of consumer market in the Sverdlovsk region.

\section{Materials and methods}

In the current context, the consumer market is going through the Regional consumer market. The ongoing global economic, social, political and environmental changes increase competition between countries and regions, and the active development of digital technologies leads to market integration and further digital services development.

The digital retail services development contributes to the increasing level of goods availability, while the negative impact of the territorial fragmentation factor is neutralized owing to the development of related services, providing the opportunity to buy goods and services in the digital space regardless of the location of the seller or buyer.

In the course of the research the authors used such methods as analysis, comparison, and grouping.

The consumer market development issues have always been of great interest to scientists, which is confirmed with a large number of scientific publications. So, theoretically, the research is based on the works by such the following authors Babaeva 
A.D. [4], Borbodoev M.M. [4], Berendeeva E.V. [5], Ratnikova T.A. [5], Grigorjeva V.N. [6], Salikhova Ya.Yu.[6], Kuznetsov E.T.[7], Fedko V.P. [7], Ganus S. [7], Golubchikova M.E. [8], Inevatova O.A. [9], Gayanova V.M. [10], Kapkh D.A. [10], Fadeeva Z.O. [10], Kramarev A.N. [11], Takhumova O.V. [12], Tereshchenko N.N. [13], ZhilinaE.V. [14], Zimin A.F. [14], Timirjanova V.M. [14], Usova N.V. [15, 16].

The multifaceted major breakthroughs in the consumer market are the driver for investigating this element of territorial socio-economic development.

Under digital transformation and the coronavirus pandemic, the importance is increasing of consumer market research and of medium term priority areas identification, considering the exceptional situation which served as a catalyst for the crisis phenomena development in the economy.

\section{Results and discussion}

In 2020, the world faced a new global challenge, which has not only became a catalyst for crisis phenomena in the economy, but also a digitization driver for the national economy sectors.

The active spread of the Covid-19 coronavirus infection has led to a number of restrictions, such as closed borders, limited international and interregional movement, transition to distant work, suspension of the activities of enterprises which were unable to transfer to digital technologies. Enterprises and organizations in various fields of activity had to reconsider their work model and implement digital tools to interact both at corporate level and with their target audience.

The same changes can be observed in the consumer market.

For better understanding of the consumer market current state and the authorities' perception of its development, we should consider the historical stages of digital retail services development.

Table 1. Retail development stages [Drawn from 17]

\begin{tabular}{|l|l|}
\hline \multicolumn{1}{|c|}{ Stage } & \multicolumn{1}{c|}{ Characteristics } \\
\hline Traditional trade & $\begin{array}{l}\text { This stage, widely used until 1950, represented trading activities in fixed retail } \\
\text { facilities. Currently, this format is under the threat of considerable decrease due } \\
\text { to the advancement of progressive retail formats, which are enjoying demand of } \\
\text { the target audience. This format will hardly disappear in the near future, but its } \\
\text { transformation and decrease in the number of traditional retail trade objects in } \\
\text { certain territories is the objective consequence. }\end{array}$ \\
\hline Distance selling & $\begin{array}{l}\text { This stage began in 1950. These days, this trading format is rapidly losing its } \\
\text { relevance, giving the way to modern formats, characterized by selling by mail, } \\
\text { catalogs or television. }\end{array}$ \\
\hline e-commerce & $\begin{array}{l}\text { This format has been developing since 1990. The main driver is the Internet, } \\
\text { where interaction is growing. Such online stores as Amazon, Alibaba, being } \\
\text { typical examples of those days, have now turned into digital platforms. }\end{array}$ \\
\hline $\begin{array}{l}\text { Multichannel } \\
\text { omnichannel }\end{array}$ & $\begin{array}{l}\text { The omnichannel and multichannel format evolved in 2007. The process of } \\
\text { interaction with the consumer is not limited to one channel, but various digital } \\
\text { platforms are used for communications. In particular, mobile internet and social } \\
\text { media. }\end{array}$ \\
\hline Digital trade & $\begin{array}{l}\text { Since 2010 digital tools, such as cloud technologies and big data are gaining } \\
\text { greater popularity. }\end{array}$ \\
\hline
\end{tabular}

The above table demonstrates that digital commerce is turnining into the objective consequence of the evolutionising retail and consumer market as a whole. The further consumer market development will be based on big data, robotics and artificial intelligence, augmented and virtual reality technologies. 
The authors believe, that the digital consumer market is an open system for providing consumer goods and services, where participant can interact wherever each of them is, and is operating digitally under external and internal factors.

In addition, several criteria can be distinguished for the digital consumer market classification.

First, the territorial level. Here, the digital consumer market can be global, regional and national.

Second is the market development trend. Here, the authors identify the intensively expanding, extensively expanding, stagnating and contracting ones. The key indicators are quantitative changes in the availability and demand for digital retail services.

The third one is the material indicator. It considers the materialization level of the final product / service for the consumer.

And next is the target consumer's income. The mass market, middle market, premium market are distinquished here.

The complex epidemiological situation and the currently acting strategic documents on national economy digitization have playd a catalysing role in the consumer market transition to online format.

Importantly, in 2019 the "Sverdlovsk regional consumer market development strategy for the period up to 2035" [18] was approved in the Sverdlovsk region, ensuring the importance of the consumer market sustainable development for the stable economic growth and social well-being of the population.

In the framework of this strategic document the following key goals for the consumer market development have been identified:

- to develop the multi-format consumer market infrastructure развитие

- to enhance trade in small, hard-to-reach and remote settlements

- to improve the service level in consumer market

It should be mentioned that this strategic document does not see retail digitization as a priority area, which, in our opinion, is wrong.

The strategic document identifies barriers hampering active digital trade development. In particular, the consumer's loyalty to certain trade enterprises, considering their territorial accessibility, delivery speed and quality of the goods.

Moreover, Internet access level, demand for online stores, and business operation costs reduction are considered to be favorable conditions.

Significantly, while in previous times digital retail services were percieved as additional format of interaction with the target audience, presently, they are the first thing and enjoy the consumers' demand.

\section{Conclusions}

In the present-day context, the advanced digital retail services offer the greatest promise and are the most relevant to the priorities of the national economy transformation, reducing the influence of the spatial aspect, ensuring the multi-format development and the consumer choice. The key factors in traditional retail services are the store location, service level and quality of the service provided. While in the period of self-isolation and digitization, the store profile, quality of products, terms of payment and delivery have become increasingly important. In turn, digital retail services provide the stores with the opportunity to retain their market share and continue interacting with the target audience, but using digital technologies. Moreover, producers and consumers can interact on various platforms (online stores, marketplaces).

Thus, it can be stated that in modern conditions, sustainable development of the consumer market is only possible through digital technologies. There is no return for the 
consumer market to the times before the pandemic, and lots of consumers find digital retail services more convenient for buying goods. For entrepreneurs, the ability to operate in digital space is a tool of retaining their market share and increasing competitiveness through the customization and personalization of the goods and services provided.

\section{References}

1. Decree of the RF President of 07.05.2018№ 204 "On national goals and strategic objectives of the Russian Federation development for the period up to 2024", http://www.kremlin.ru

2. "The RF digital economy", https://digital.gov.ru

3. Project "E-commerce development strategy in the Russian Federation for the period up to 2025", https://minpromtorg.gov.ru

4. M.M.Borbodoev, A.D. Babaeva, Actual problems of the humanities and natural sciences, 5-2 (2016)

5. E.V.Berendeeva,T.A. Ratnikova, Economic Journal of the Higher School of Economics, 22,1(2018)

6. V.N.Grigorieva, Ya.Yu. Salikhova, Marketing management in the digital economy, 2, 2 (2016)

7. E.T.Kuznetsov, V.P.Fedko, S. Ganus, TerraEconomicus, 4 (2005)

8. M.E. Golubchikova, Enterprise strategy in the context of increasing its competitiveness, 5-2 (2016)

9. O.A. Inevatova, Vestnik OSU, 2 (108) (2010)

10. D.A.Karkh, V.M. Gayanova,Z.O. Fadeeva, Manager, 5 (69) (2017)

11. A.N. Kramarev, Economics and management, 3 (35) (2008)

12. O.V.Takhumova, Bulletin of the North Caucasus State Technical University, 4 (2006)

13. N.N. Tereshchenko, Problems of modern economics, 3 (2008)

14. V.M.Timirjanova, A.F. Zimin, E.V. Zhilina, Economy of the region, 14, 1 (2018)

15. N.V. Usova, Regional economy: theory and practice, 31 (358) (2014)

16. N.V. Usova, R-Economy, 3,1 (2017)

17. Technology and leadership in digital retail, https://www.pwc.ru

18. Consumer market development strategy of the Sverdlovsk region for the period of up to2035, http://www.pravo.gov66.ru 